\title{
ПРО ЗАКОНИ РОЗВИТКУ ТА ФУНКЦІОНУВАННЯ ВИДАВНИЧО-ПОЛІГРАФІЧНОЇ ГАЛУЗІ
}

() О. В. Мельников, К.т.н., В. М. Сеньківський, д.т.н., професор, А. М. Штангрет, д.е.н., доцент, УАД,

Е. П. Семенюк, д.філософ.н., професор, Національний лісотехнічний університет України, Львів, Україна

\section{Проанализированы законы развития и функционирования издательско-полиграфической отрасли, позволяющие научно объяснить существующие явления, события, факты и предсказывать новые.}

Analyzed the laws of development and functioning of publishing and printing industry, allowing science to explain existing phenomena, facts and predict new.

Як відомо, наука починається із спостереження. Рівень розвитку науки характеризується не стільки кількістю знайдених емпіричних даних, скільки встановленням необхідних зв'язків між ними, об'єднанням їх у рамках єдиної теоретичної системи. Наукове дослідження має справу не з окремими, ізольованими проблемами, а з певною їх системою.

Класифікація і систематизація явищ, що вивчаються, складає початковий етап розвитку науки. Всі зрілі, розвинені науки, як правило, порівняно давно пройшли цей етап. На описовій і напівемпіричній стадії наука обмежується координацією накопиченого дослідного матеріалу. Подальший прогрес її неминуче пов'язаний 3 переходом від простої координації до субординації різних складових її елементів. Використання апарату математики і логіки дає можливість краще зрозуміти внутрішній зв'язок між різними елементами наукової теорії, уточнює її структуру і значно підсилює ефективність її передбачень.

Наукові пояснення спираються на точно сформульовані закони, поняття і теорії, які відсутні в буденному пізнанні. Тому адекватність і глибина пояснення явищ і подій, що оточують нас, багато в чому залежать від міри проникнення науки в об'єктивні закономірності управління цими явищами і подіями. Своєю чергою самі закони можна посправжньому зрозуміти лише в рамках відповідної наукової теорії, хоча вони і служать тим концептуальним ядром, довкола якого будується теорія.

Як відомо, закон - необхідне, істотне, стійке, повторюване відношення між явищами в природі і суспільстві [19, 21]. Внутрішній механізм розвитку об'єктивних законів пов'язаний з переходом кількісних змін в якісні. Цей процес здійснюється не від випадку до 
випадку, а діє завжди, якщо, звичайно, змінюються умови, що зачіпають саму внутрішню структуру відношення, що виражає цей закон, а не відбувається просте його поширення в просторі і якщо ця зміна умов здійснюється достатньо довго. При цьому змінюються всі елементи закону - і його форма, і його зміст, тобто суть. Наукові закони можна характеризувати певною мірою зрілості. Адже вони, як і описувані ними явища виникають, розвиваються і згодом втрачають силу.

Наукові закони формулюються людьми, тому вони можуть бути і не абсолютними, тобто остаточним вираженням об'єктивної істини (так проявляє себе єдність абсолютної та відносної істини у пізнанні світу). Однак ці закони обов'язково мають бути вираженням певних вірогідних процесів, певної об'єктивної істини - вираженням, поза сумнівом, відносним і в той же час об'єктивним. Вони знаменують той або інший етап безперервного наближення людини до абсолютної істини. Кібернетика відкрила, що будь-який досить змістовний фрагмент реальності незалежно від його природи і речового субстрату можна розглядати як складну динамічну систему [14].

Видавничо-поліграфічну галузь слід розглядати як систему, до складу якої повинні бути включені такі елементи, як авторське середовище, видавничі структури, поліграфічні підприємства, книготорговельні організації та читацьке середовище [10-13, 15]. Сукупність цих елементів, об'єднаних однією програмою та єдиною метою, і утворює один з програмних господарських комплексів. Наявні елементи (підсистеми) видавничо-поліграфічної галузі забезпечують відносно замкнений характер системи і зумовлюють іï працездатність, тобто успішне вирішення поставлених перед нею завдань.

Запропоновані та розглянуті нами далі закони розвитку і функціонування видавничополіграфічної галузі дають можливість науково пояснити явища, що цікавлять нас, події, факти і одночасно 3 цим дозволяють передбачати нові, невідомі явища, адже вірогідне наукове пояснення володіє потенційною пророчою силою. При цьому потрібно не забувати, що більшість узагальнень і висновків природознавства та інших наук мають не абсолютно вірогідний, а лише імовірнісний характер.

Спираючись на закони, наука дістає можливість не тільки пояснювати існуючі факти і події, але і передбачати нові. Без цього немислима свідома, цілеспрямована практична діяльність [18]. У літературі описані екологічні закони [5, 9], закони розвитку технічних систем [1], сільськогосподарського виробництва [2], економіки транспорту [20]. Автори даної статті вважають, що сьогоднішній рівень наших знань про особливості функціонування видавничо-поліграфічної галузі дозволяє сформулювати деякі загальні закони iii розвитку та функціонування, які умовно можна поділити на три групи: рівноваги галузевої 
системи; руху системи; розвитку галузі.

Закони рівноваги галузевоі системи визначають умови нормального функціонування видавничо-поліграфічної галузі (ВПГ). Для того, щоб система виявилася життєздатною, мають виконуватися наступні закони:

Закон повноти частин системи. Необхідною умовою принципової життєздатності системи $€$ наявність і мінімальна працездатність усіх частин системи. Згідно з цим законом, ВПГ повинна включати п'ять основних підсистем: авторське середовище, видавничі структури (BC), поліграфічні підприємства (ПП), книготорговельні організації та читацьке середовище. Сенс закону в тому, що для нормальної працездатності системи необхідна наявність цих п'яти підсистем та їх мінімальна придатність до функціонування у складі даної галузевої системи.

В основі спільного функціонування усіх елементів в межах певної системи лежить поєднання інтересів через створення продукту для задоволення інформаційних потреб споживача, уможливлення самореалізації автора, отримання прибутку видавничих структур, поліграфічних підприємств та книготорговельних організацій. Існують випадки коли певний елемент, для більш повного задоволення власного інтересу, здійснює виконання функцій інших складових системи, наприклад видавництва самостійно здійснюють реалізацію продукції, але в такому випадку мова йде про диверсифікацію діяльності і поєднання кількох видів діяльності, коли принцип функціонування самої системи не змінюється. Система не є ізольована, вона відкрита як в процесі надходження сировини, матеріалів та інформації, так на предмет виникнення обмежень щодо функціонування в певних географічних межах.

Наприклад, наявність обмежень при ввезенні на митну територію України певних груп устаткування за одночасної стагнації вітчизняного поліграфічного машинобудування призводила свого часу до неможливості модернізації парку устаткування та, відповідно, до погіршення якості друкованої продукції. Отож за потреби виготовити продукцію підвищеної якості видавництва змушені були звертатися до іноземних виробників поліграфічної продукції. Зрозуміло, що продукція кращої якості користувалася більшим попитом потенційних споживачів.

Використання цього закону дозволяє представити і перевірити основні економічні рішення в системі і їх логічну відповідність, виходячи із загальносистемних функцій.

Закон наскрізного руху інформації в системі. Необхідною умовою принципової життєздатності ВПГ як економічної системи є наскрізний рух інформації по усіх її частинах. Тут доречно нагадати слова академіка В. М. Глушкова: «/нформація в найзагальнішому iї розумінні є... мірою змін, якими супроводжуються всі процеси, що відбуваються у світі. Аб- 


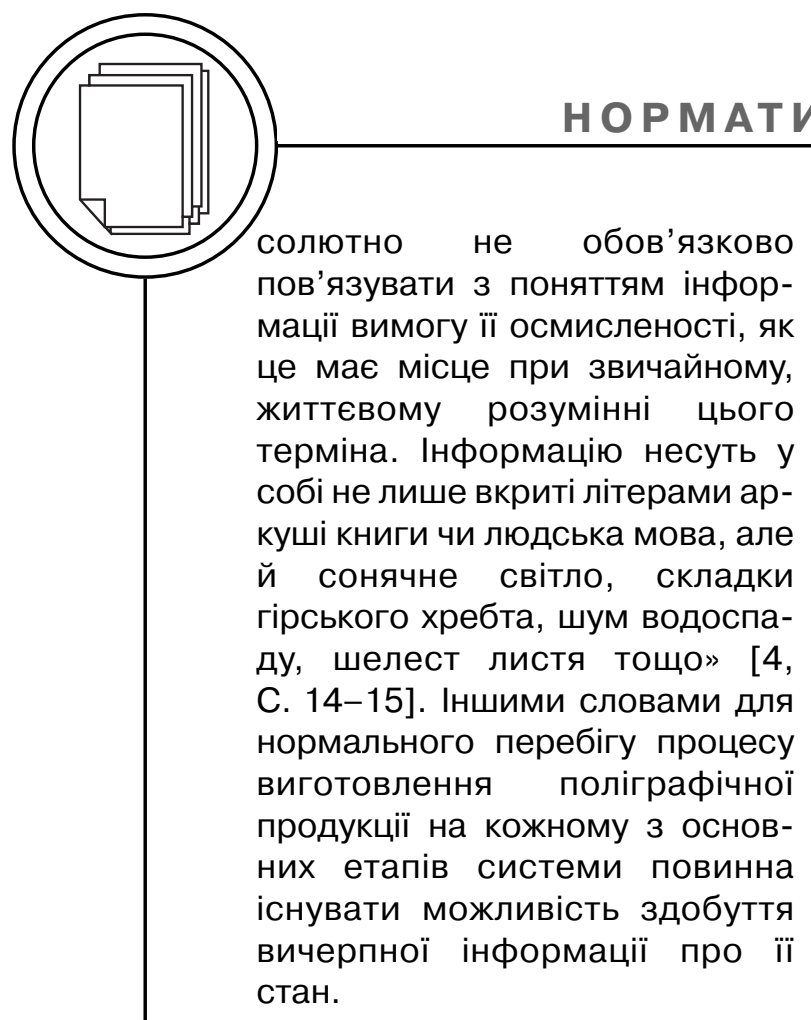

Інформація з читацького середовища про зміну попиту, динаміку потреби в певному виді продукції, потребі в якості та платоспроможності споживача надходить до автора, ВС, ПП і виконує мотивуючу функцію, спонукає до підприємницької діяльності, надаючи можливість отримати прибуток як джерело подальшого розвитку. У свою чергу, отримана з видавничої продукції інформація робить можливим генерування нових знань - джерело суспільного розвитку у наш час.

Наприклад, для ВС принциповим $€$ своєчасне й повне отримання інформації від ПП про собівартість виготовлення продукції, адже відповідно до отриманої інформації видавництво розраховує ціну продукції, що відпускається книжковій торгівлі, розраховується авторська винагорода тощо.

Закон узгодження ритмічності частин системи. Необхідною умовою принципової життєздатності ВПГ є узгодження ритмічності роботи всіх частин системи.

Оскільки сьогодні у ВПГ ми маємо справу з потоковим виробництвом, продуктивність роботи окремих частин системи має бути узгоджена, бо величина неузгодженості істотно впливає на показники ефективності, зокрема, на продуктивність обладнання і якість продукції. Тобто, у випадку випуску будь-якого видання видавництво готує його до друку, друкарня виготовляє його за певний термін (закуповує матеріали та визначає календарний графік проходження замовлення), далі це видання поступає у продаж.

Тенденцією останніх десятиліть - задоволення індивідуальних потреб споживача, а відтак виникає потреба в узгоджені дій між складовими системи.

Закони руху системи визначають еволюцію ВПГ незалежно від конкретних технічних і економічних чинників, що обумовлюють цей розвиток.

Закон досягнення оптимальності системи через безперервне удосконалення ефективного використання наявних ресурсів.

Розвиток всіх систем йде у напрямі збільшення міри ідеальності. Згідно з цим законом, удосконалення технологічних процесів ВПГ виявляється в тому, що значення його основних параметрів з розрахунку на одиницю корисного ефекту постійно зменшується, прагнучи до ідеального процесу, тобто до такого, якого реально не має, але його функції виконуються. 
Це означає, що навіть в разі впровадження нових схем управління чи модернізації технологічного устаткування вартість виконуваних при цьому робіт постійно зменшується, а якість продукції покращується. Тобто, використання цього закону при проектуванні процесів виготовлення та просування продукції орієнтує розробників на підвищення якості технологічного процесу та його економічної ефективності.

Закон нерівномірного розвитку частин системи. Розвиток частин ВПГ йде нерівномірно: чим складніше система, тим більш нерівномірним $є$ розвиток їі частин. Тобто будь-яке удосконалення системи має бути спрямоване на зменшення розриву між рівнями розвитку її підсистем.

Дія цього закону наочно ілюструє те, як нерівномірно розвивалося спочатку технічне забезпечення друкарських процесів і відставав від них розвиток видавничих-додрукарських (якщо під ними розуміти підготовку видання у видавництві), потім як динамічно почали розвиватися додрукарські процеси за допомогою інформаційних технологій і як тільки нещодавно почали застосовувати такі технології у книжковій торгівлі з метою просування продукції до споживача.

Закон переходу до системи вищого рівня. Вичерпавши можливості розвитку, система переходить на вищий рівень як одна з його частин; при цьому її подальший розвиток здійснюється за допомогою сучасних технічних засобів та, можливо, нових принципів.
На сьогоднішній день логіка вдосконалення видавничих (додрукарських) процесів призвела до можливості переносити інформацію з комп'ютера на друкарську форму, тобто відбувається процес спрощення отримання друкованої інформації. у зв'язку із цим у багатьох випадках ми бачимо фактичне об'єднання видавничих структур і поліграфічних підприємств. Подальший розвиток ВПГ також передбачає поступову заміну матеріальної форми книги з паперової на електронну, тобто збільшення частки електронної книги та більш активне використання електронних ЗМК для отримання оперативної інформації про оточуючий світ.

Закони розвитку системи відображають розвиток ВПГ під дією конкретних технічних і економічних чинників. Закони цього типу визначають поточні тенденції розвитку галузевої системи.

Закон невідповідності репродукції оригіналу. Потреба в організації поточного виробництва вимагає розглядати весь технологічний ланцюжок як систему, функції елементів якої повинні бути точно узгоджені одна з одною. Закономірним $є$ бажання досягти на репродукції таких же оптичних густин, які мають відповідні ділянки оригіналу, тобто отримати репродукцію, ідентичну оригіналу.

Однак у більшості випадків отримати градаційно точну репродукцію неможливо. Це пов'язано із рядом факторів, 3 яких найбільш суттєвий - недостатня оптична густина друкарської фарби. Тому інтервал 
оптичних густин відбитка завжди менше інтервалу оригінала. Досі не вирішено однозначно, якою у цих умовах повинна бути репродукція. Існує декілька думок. Узагальнюючи, можна звести їх до двох: відтворення повинно бути лінійним чи відтворення повинно забезпечити хорошу передачу сюжетно-важливих деталей [8, 17].

Закон накопичення якості на кожному етапі функціонування системи. Говорячи про якість друкованої продукції, необхідно завжди мати на увазі поетапне накопичення якості видання, що є наслідком виконання всього технологічного циклу підготування та випуску видань. Тобто відбувається об'єднання або своєрідне логічне додавання часток якості видання на кожному наступному етапі його виготовлення, у результаті чого формується прогнозована інтегральна якість продукції.

Накопичення якості майбутнього видання здійснюється не тільки в послідовності технологічних етапів, а й у якісній реалізації віднесеної до нього множини факторів, що визначають суть етапу та сукупність дій. Результати сукупного опрацювання дій та факторів зумовлюють певну якість результату при завершенні кожного з технологічних етапів виготовлення друкованої продукції [3].

Закон залежності інтенсивності розвитку ВПГ від купівельної спроможності споживача. Асортимент продукції ВПГ дуже широкий й має суттєві відмінності не лише за складом, змістом і призначенням, але і за рівнем пріоритетності для споживача. Наприклад, будучи складовою товарів першої необхідності упаковка харчових товарів, попит на які змінюється з часом несуттєво, завжди буде належати до пріоритетних для людини. Книжка чи періодичне видання - не може належати до товарів першої необхідності, а відтак зниження купівельної спроможності населення суттєво впливає на обсяги виробництва цього виду продукції. Чим вищий рівень добробуту населення певної країни, тим більше потреб воно може задовольнити, тим вищі темпи розвитку ВПГ.

Існує взаємозалежність між рівнем добробуту населення і розвитком ВПГ. Дослідження доводять, що попит на друковану продукцію (індекс попиту) залежить від добробуту населення (ВВП у розрахунку на одну особу). Наявність цієї залежності дозволяє із великим ступенем імовірності розрахувати можливий обсяг друкованої продукції [6, 7, 16, 22, 23].

Таким чином, маючи в своєму розпорядженні певну теорію, можемо заздалегідь сказати, які емпіричні дані слід шукати, за яких умов їх можна виявити. Існує думка, що відкриття нових, цікавих для науки фактів залежить винятково від випадку. Навряд чи можна з цим погодитися, оскільки під час пошуку нових фактів і навіть при плануванні майбутніх спостережень і експериментів учений керується (можливо, підсвідомо) певними теоретичними уявленнями. Без відповідної інтерпретації самі факти 
залишаться незрозумілими, а тому і не зможуть бути виявленими. Інтерпретація передбачає звернення або до існуючої теорії, або до елементів новост- ворюваної теорії. Саме в цьому вбачається сенс науково-методологічної діяльності з осмислення законів розвитку та функціонування ВПГ.

1. Альтшулер Г. С. Творчество как точная наука : Теория решения изобретательских задач / Г. С. Альтшулер. - М. : Сов. радио, 1979. - 176 с. 2. Бардин И. А. Методологические вопросы сельскохозяйственной науки : учебн. пособие / И. А. Бардин. - М. : Высшая шк., 1975. - 144 с. 3. Гавенко С. Ф. Інтегральний прогноз якості книжкових видань / С. Ф. Гавенко, В. М. Сеньківський, Н. Є. Сеньківська // Наук. зап. (Укр. акад. друкарства). - 2012. - № 1(38). - С. 144-148. 4. Глушков В. М. Кибернетика. Вопросы теории и практика. - М. : Наука, 1986. - 488 с. - (Наука. Мировоззрение. Жизнь). 5. Джигирей В. С. Екологія та охорона навколишнього природного середовища : навч. посіб. / В. С. Джигирей. - 5-те вид., виправ. і доп. К. : Знання, 2007. - 422 с. 6. Дурняк Б. В. Видавнича справа та поліграфічна діяльність в Україні : моногр. / Б. В. Дурняк, А. М. Штангрет, О. В. Мельников, Я. М. Угрин. - Львів : Укр. акад. друкарства, 2009. 150 с. 7. Дурняк Б. В. Видавничо-поліграфічна галузь України : Стан, проблеми, тенденції. Статистично-графічний огляд : моногр. / Б. В. Дурняк, А. М. Штангрет, О. В. Мельников. - Львів : Укр. акад. друкарства, 2006. 274 с. 8. Име Р. Репродукционная техника : пер. с нем. / Р. Име. - М. : Книга, 1985. - С. 302-305. 9. Коммонер Б. Замыкающийся круг. Природа. Человек. Технологии : пер. с англ. / Б. Коммонер. - Л. : Гидрометиоиздат, 1974. - 279 с. 10. Машталир Р. М. Экономические проблемы научно-технического прогресса в полиграфии : [моногр.] / Р. М. Машталир. - М. : Книга, 1978. - С. 3-53. 11. Машталир Р. М. Системный поход - основа совершенствования планирования научно-технического прогресса / Р. М. Машталир // Полиграфия. - 1976. - № 6. - С. 21-22. 12. Машталір Р. М. Дослідження видавничо-поліграфічного комплексу як економічної системи / Р. М. Машталір // Поліграфія і видавнича справа. - 1977. - Вип. 13. С. 93-99. 13. Машталір Р. М. Удосконалення управління видавничополіграфічною діяльністю на основі системного підходу / Р. М. Машталір // Поліграфія і видавнича справа. - 1978. - № 14. - С. 99-105. 14. Новик И. Б. Вопросы стиля мышления в естествознании : [моногр.] / И. Б. Новик. - М. : Политиздат, 1975. - С. 114. 15. Олянишен Т. В. Моделі інформаційної технології автоматизованого прогнозування процесу комунікативного руху книги до читача : автореф. дис... канд. техн. наук : 05.13.06 / Тетяна Вікторівна Олянишен ; [Укр. акад. друкарства]. - Львів, 2010. 20 с. 16. Олянишен Т. В. Побудова моделі ринку друкованої продукції України / Т. В. Олянишен, А. М. Штангрет // Технол. і техн. друкарства. 2009. - № 3-4(25-26). - С. 151-159. 17. Оптика фотографических систем : в 2-х чч. : Ч. ІІ. Основы растрового процесса / сост. : Б. А. Шашлов, Е. Б. Козлова, Ю. С. Андреев. - М. : Изд-во Москов. полигр. ин-та, 1988. С. 10-13. 18. Рузавин Г. И. Методы научного исследования : [моногр.] / Г. И. Рузавин. - М. : Мысль, 1974. - С. 162-163. 19. Румянцев А. М. Инструментарий экономической науки и практики. Научно-популярный практикум / А. М. Румянцев, Е. Г. Яковенко, С. И. Янаев. - М. : Знание, 
1985. - С. 14. 20. Сич Є. М. Закони економіки транспорту : моногр. / Є. М. Сич, В. М. Кислий. - Ніжин : Аспект-Поліграф, 2009. - 160 с. 21. Философский энциклопедический словарь / гл. редакция : Л. Ф. Ильичев, П. Н. Федосеев, С. М. Ковалев, В. Г. Панов. - М. : Сов. Энциклопедия, 1983. - 840 с. 22. Читання як проблема вільного часу : За результатами соціолого-статистичних досліджень : моногр. / В. М. Сеньківський, Т. В. Олянишен, А. М. Штангрет, О. В. Мельников. Львів : Укр. акад. друкарства, 2009. - 160 с. 23. Чеснаков В. А. Полиграфия России - шаг в третье тысячелетие : [сб. мат.] / В. А. Чеснаков, Н. В. Сакиян, А. Е. Шварц, И. Н. Смиренный и др. - М. : Август Борг, 2002. $-544 \mathrm{c}$.

1. Al'tshuler G. S. Tvorchestvo kak tochnaja nauka : Teorija reshenija izobretatel'skih zadach / G. S. Al'tshuler. - M. : Sov. radio, 1979. - 176 s. 2. Bardin I. A. Metodologicheskie voprosy sel'skohozjajstvennoj nauki : uchebn. posobie / I. A. Bardin. - M. : Vysshaja shk., 1975. - 144 s. 3. Havenko S. F. Intehralnyi prohnoz yakosti knyzhkovykh vydan / S. F. Havenko, V. M. Senkivskyi, N. le. Senkivska // Nauk. zap. (Ukr. akad. drukarstva). - 2012. - № 1(38). S. 144-148. 4. Glushkov V. M. Kibernetika. Voprosy teorii i praktika. - M. : Nauka, 1986. - 488 s. - (Nauka. Mirovozzrenie. Zhizn'). 5. Dzhyhyrei V. S. Ekolohiia ta okhorona navkolyshnoho pryrodnoho seredovyshcha : navch. posib. / V. S. Dzhyhyrei. - 5-te vyd., vyprav. i dop. - K. : Znannia, 2007. 422 s. 6. Durniak B. V. Vydavnycha sprava ta polihrafichna diialnist $\vee$ Ukraini : monohr. / B. V. Durniak, A. M. Shtanhret, O. V. Melnykov, la. M. Uhryn. - Lviv : Ukr. akad. drukarstva, 2009. - 150 s. 7. Durniak B. V. Vydavnycho-polihrafichna haluz Ukrainy : Stan, problemy, tendentsii. Statystychno-hrafichnyi ohliad : monohr. / B. V. Durniak, A. M. Shtanhret, O. V. Melnykov. - Lviv : Ukr. akad. drukarstva, 2006. - 274 s. 8. Ime R. Reprodukcionnaja tehnika : per. s nem. / R. Ime. - M. : Kniga, 1985. - S. 302-305. 9. Kommoner B. Zamykajushhijsja krug. Priroda. Chelovek. Tehnologii : per. s angl. / B. Kommoner. - L. : Gidrometioizdat, 1974. - 279 s. 10. Mashtalir R. M. Jekonomicheskie problemy nauchno-tehnicheskogo progressa v poligrafii : [monogr.] / R. M. Mashtalir. M. : Kniga, 1978. - S. 3-53. 11. Mashtalir R. M. Sistemnyj pohod - osnova sovershenstvovanija planirovanija nauchno-tehnicheskogo progressa / R. M. Mashtalir // Poligrafija. - 1976. - № 6. - S. 21-22. 12. Mashtalir R. M. Doslidzhennia vydavnycho-polihrafichnoho kompleksu yak ekonomichnoi systemy / R. M. Mashtalir // Polihrafiia i vydavnycha sprava. - 1977. - Vyp. 13. S. 93-99. 13. Mashtalir R. M. Udoskonalennia upravlinnia vydavnycho-polihrafichnoiu diialnistiu na osnovi systemnoho pidkhodu / R. M. Mashtalir // Polihrafiia i vydavnycha sprava. - 1978. - № 14. - S. 99-105. 14. Novik I. B. Voprosy stilja myshlenija $v$ estestvoznanii : [monogr.] / I. B. Novik. - M. : Politizdat, 1975. - S. 114. 15. Olianyshen T. V. Modeli informatsiinoi tekhnolohii avtomatyzovanoho prohnozuvannia protsesu komunikatyvnoho rukhu knyhy do chytacha : avtoref. dys... kand. tekhn. nauk : 05.13.06 / Tetiana Viktorivna Olianyshen ; [Ukr. akad. drukarstva]. — Lviv, 2010. - 20 s. 16. Olianyshen T. V. Pobudova modeli rynku drukovanoi produktsii Ukrainy / T. V. Olianyshen, A. M. Shtanhret // Tekhnol. i tekhn. drukarstva. - 2009. - № 3-4(25-26). - S. 151-159. 17. Optika fotograficheskih sistem : v 2-h chch. : Ch. II. Osnovy rastrovogo processa / sost. : B. A. Shashlov, E. B. Kozlova, Ju. S. Andreev. - M. : Izd-vo Moskov. poligr. in-ta, 1988. - S. 10-13. 18. Ruzavin G. I. Metody nauchnogo issledovanija : [monogr.] / G. I. Ruzavin. - M. : Mysl', 1974. S. 162-163. 19. Rumjancev A. M. Instrumentarij jekonomicheskoj nauki i prak- 
tiki. Nauchno-populjarnyj praktikum / A. M. Rumjancev, E. G. Jakovenko, S. I. Janaev. - M. : Znanie, 1985. - S. 14. 20. Sych le. M. Zakony ekonomiky transportu : monohr. / le. M. Sych, V. M. Kyslyi. - Nizhyn : Aspekt-Polihraf, 2009. - 160 s. 21. Filosofskij jenciklopedicheskij slovar' / gl. redakcija : L. F. Il'ichev, P. N. Fedoseev, S. M. Kovalev, V. G. Panov. - M. : Sov. Jenciklopedija, 1983. - 840 s. 22. Chytannia yak problema vilnoho chasu : Za rezultatamy sotsioloho-statystychnykh doslidzhen : monohr. / V. M. Senkivskyi, T. V. Olianyshen, A. M. Shtanhret, O. V. Melnykov. - Lviv : Ukr. akad. drukarstva, 2009. - 160 s. 23. Chesnakov V. A. Poligrafija Rossii - shag v tret'e tysjacheletie : [sb. mat.] / V. A. Chesnakov, N. V. Sakijan, A. E. Shvarc, I. N. Smirennyj i dr. - M. : Avgust Borg, 2002. - 544 s.

$$
\begin{array}{r}
\text { Рецензент - О. М. Величко, д.т.н., } \\
\text { професор, НТУУ «КПІ» }
\end{array}
$$

Надійшла до редакції 19.12.13 